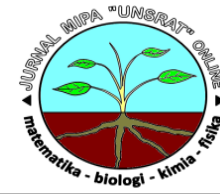

\title{
Uji Aktivitas Antiinflamasi Ekstrak Etanol Tanaman Patah Tulang (Euphorbia tirucalli L.)
}

\author{
Christina S. H. Garakia ${ }^{*}$,Meiske Sangia, Harry S.J.Koleangana
}

aJurusan/Prodi.Kimia, Fakultas MIPA, Universitas Sam Ratulangi

\begin{tabular}{l} 
K A T A K U N C I \\
\hline Antiinflamasi \\
Euphorbia tirucalli \\
Karagenan
\end{tabular}

A B S T R A K
Penelitian ini bertujuan untuk menguji aktivitas antiinflamasi ekstrak etanol
tanaman patah tulang (Euphorbia tirucalli L.) terhadap udem yang
ditimbulkan oleh karagenan pada telapak kaki tikus. Ekstrak etanol
tanaman patah tulang dibuat dengan teknik maserasi selama 24 jam
menggunakan pelarut etanol $80 \%$. Pengujian dilakukan dengan metode
induksi karagenan menggunakan hewan uji tikus putih jantan galur wistar
sebanyak 15 ekor dibagi menjadi 5 kelompok perlakuan. Kelompok
pertama sebagai kontrol negatif dengan pemberian Carboxy Methyl
Cellulose (CMC) 1\%, kelompok kedua sebagai kontrol positif diberikan
Natrium Diklofenak, kelompok ketiga diberi ekstrak etanol tanaman patah
tulang dosis $5 \%$, kelompok keempat dan kelima diberi ekstrak etanol
tanaman patah tulang dengan dosis $10 \%$ dan dosis $15 \%$. Hasil penelitian
menunjukkan adanya aktivitas antiinflamasi pada pemberian ekstrak
etanol tanaman patah tulang dosis $5 \%$, dosis $10 \%$ dan dosis $15 \%$ karena
setara dengan kontrol positif dan berbeda dengan kontrol negatif. Dosis
yang paling baik dalam penghambatan radang adalah dosis $10 \%$ yang
ditinjau dari pengukuran volume udem, persen volume dan persen inhibisi
udem.

K E Y W O R D S

Antiinflammatory

Euphorbia tirucalli

Carrageenan

\begin{abstract}
A B S T R A C T
This study was aimed to examine the anti-inflammatory activity of ethanol extracts of patah tulang (Euphorbia tirucalli L.) plant against edema caused by carrageenan in the soles of rat feet. Ethanol extract of patah tulang plant was obtained by maceration for 24 hours using ethanol $80 \%$. The test was carried out by carrageenan induction method using 15 white wistar male rats divided into 5 treatment groups. The first group as a negative control was given 1\% Carboxy Methyl Cellulose (CMC), the second group as a positive control was given dichlophenac sodium, and the third, fourth and fifth groups were given ethanol extracts of $5 \%, 10 \%$ and $15 \%$, respectively The results showed anti-inflammatory activity in ethanol extracts of patah tulang plants at $5 \%, 10 \%$ and $15 \%$ because they were equivalent to positive control and different from negative control. The best dose for inflammation inhibition was the $10 \%$ dose in terms of edema voleme, percent volume and percent inhibition of edema
\end{abstract}

TERSEDIA ONLINE

01 Agustus 2020

\section{Pendahuluan}

Seiring dengan kemajuan teknologi, penggunaan obat herbal masih banyak digemari oleh masyarakat. Hal tersebut disebabkan obat herbal mempunyai banyak keuntungan, antara lain: harga yang relatif murah sehingga dapat dijangkau masyarakat luas, praktis dalam pemakaian, bahan baku yang mudah diperoleh dan disamping itu efek samping penggunaan obat herbal yang sejauh ini dianggap lebih kecil daripada efek samping obat sintetik jika digunakan secara tepat (Sari, 2006). Ketepatan itu

*Corresponding author:

Email address: christinashgaraki@gmail.com Published by FMIPA UNSRAT (2020) 
menyangkut tepat dosis, cara dan waktu penggunaan serta pemilihan bahan ramuan yang sesuai dengan indikasi penggunaannya.

Salah satu penyakit yang banyak diobati dengan tanaman obat adalah inflamasi atau peradangan. Inflamasi adalah suatu usaha tubuh untuk merusak organisme yang menyerang, menghilangkan zat iritan, dan mengatur derajat perbaikan jaringan.

Jika terjadi proses penyembuhan, biasanya peradangan akan mereda (Mycek, 2001). Tanaman yang biasa digunakan dan dipercaya dapat menyembuhkan radang yaitu tanaman patah tulang. Berdasarkan informasi dari masyarakat Bitung, tanaman Patah tulang merupakan tanaman obat yang digunakan secara empiris untuk mengobati patah tulang akibat kecelakaan atau terjatuh. Cara penggunaannya, batang tanaman ditumbuk halus dan ditempelkan pada daerah yang sakit. Tanaman Patah tulang juga dapat digunakan sebagai antikanker, anti-tumor, anti-radang, penyakit kulit, dan pengobatan penyakit sifilis (Agral et al., 2013; Mangan, 2009).

Tanaman patah tulang yang mempunyai nama latin dari Famili Euphorbiaceae ini sangat mudah tumbuh di daerah tropis dan dapat dikembangkan secara stek. Tanaman patah tulang merupakan salah satu tanaman yang mempunyai sifat toksik terhadap kulit dari lapisan lendir. Getahnya yang berwarna putih seperti susu, bersifat toksik (Julianus, 2011). Ranting mengandung glikosida, sapogenin, dan asam elagat (Dalimartha, 2003). Dari beberapa senyawa yang digunakan adalah sapogenin, salah satu manfaat sapogenin adalah mempengaruhi kolagen (tahap awal perbaikan jaringan) dengan cara menghambat produksi jaringan luka yang berlebihan (Setyoadi dan Sartika, 2010). Tanaman ini sebelumnya telah diteliti bahwa getah dari tanaman patah tulang mengandung getah asam (latex acid) yang mengandung euphol, taraksasterol, lakterol, kutschuk (zat karet), alkaloid, flavonoid, steroid, tanin, triterpenoid dan hidroquinon (Toana dan Nasir, 2010).

Menurut Morshed (2011) efek antiinflamasi dapat dilihat dari kandungan yang terdapat pada suatu tanaman yaitu: senyawa golongan alkaloid, flavonoid, saponin, steroid dan tanin. Penelitian sebelumnya juga menunjukkan bahwa penggunaan ekstrak tanaman patah tulang memiliki aktifitas antibakteri yang dapat mencegah infeksi pada luka (Yi et al., 2017). Saat ini belum ada kajian ilmiah tentang manfaat tanaman patah tulang sebagai antiinflamasi, sehingga perlu dilakukan dilakukan suatu kajian ilmiah tentang manfaat tanaman patah tulang sebagai antiinflamasi. Tujuan dari penelitian ini untuk menguji aktivitas antiinflamasi ekstrak etanol tanaman patah tulang terhadap udem yang ditimbulkan oleh karagenan pada telapak kaki tikus.

\footnotetext{
Material dan Metode

\section{Alat dan Bahan}

Bahan yang digunakan yaitu tanaman patah tulang yang diambil dari Tompaso, Sulawesi Utara.
}

tikus putih jantan galur wistar sebanyak 15 ekor yang diambil dari desa Kamanga, Kabupaten Minahasa Tenggara, Etanol, Aquades, Carboxy Methyl Cellulose (CMC) 1\%, Natrium diklofenak, Karagenan, Iarutan $\mathrm{NaCl}$.

Alat-alat yang digunakan yaitu alat-alat gelas, oven, timbangan analitik, rotary evaporator, jarum sonde, jarum suntik, kandang tikus, dan stopwatch

\section{Preparasi Sampel}

Tumbuhan patah tulang dicuci, dipotong kecilkecil, kemudian dikeringanginkan selama kurang lebih 7 hari. Setelah kering tumbuhan patah tulang diblender sehingga didapatkan serbuk patah tulang. Kemudian serbuk yang diperoleh diayak menggunakan ayakan 65 mesh.

\section{Ekstraksi}

Sampel sebanyak 100 g diekstraksi dengan pelarut etanol menggunakan metode ekstraksi maserasi. Sampel didiamkan dalam $400 \mathrm{~mL}$ etanol selama 24 jam dan diaduk. Filtrat disaring dan ampas dipisahkan dari filtrat menggunakan kertas saring dan dievaporasi menggunakan rotary evaporator. Ekstrak yang yang didapat didinginkan di dalam desikator.

\section{Uji antiinflamasi}

Uji efek antiinflamasi mengikuti Sutrisna et al. (2010), hewan uji yang digunakan untuk pengujian sebanyak 15 ekor tikus putih jantan galur wistar dibagi dalam 5 kelompok perlakuan yang tiap kelompok terdiri dari 3 ekor. Semua tikus diaklimatisasi terhadap lingkungan minimal 1 minggu. Sebelum dilakukan pengujian hewan uji dipuasakan selama 18 jam (minum tetap diberikan) sebelum pengujian. Perlakuan pada tikus putih jantan dilakukan secara peroral dengan menggunakan jarum sonde.

Kelompok I : Diberi CMC 1\% (kontrol negatif)

Kelompok II : Diberi Natrium Diklofenak (kontrol positif)

Kelompok III : Diberi ekstrak etanol tanaman patah tulang 5\%

Kelompok IV : Diberi ekstrak etanol tanaman patah tulang 10\%

Kelompok V : Diberi ekstrak etanol tanaman patah tulang 15\%

Satu jam sebelum pengujian pemberian kontrol negatif (CMC), kontrol positif (natrium diklofenak) dan masing-masing ekstrak etanol tanaman patah tulang, setiap tikus diinduksi karagenan sebanyak $0,5 \mathrm{ml}$ pada salah satu kaki secara subplantar. Volume udem kaki tikus diukur selama 6 jam dengan interval waktu pengukuran setiap 1 jam menggunakan alat pengukur (gelas ukur).

\section{Analisa data}

Data yang diperoleh dari hasil penelitian dianalisis menggunakan program statistika metode SPSS ver.21 dengan uji Kolmogorov-Smirnov untuk melihat distribusi data dan dianalisis dengan uji 
Levene untuk melihat homogenitas data. Jika data terdistribusi normal dan homogenitas maka dilanjutkan dengan uji Analisis of Varians (ANOVA) satu arah dengan taraf kepercayaan 95\% sehingga dapat diketahui apakah perbedaan yang diperoleh bermakna atau tidak. Jika terdapat perbedaan bermakna, dilanjutkan dengan uji Beda Nyata Terkecil (BNT) dengan metode Least Significant Difference (LSD) (Santoso, 2008).

\section{Hasil dan Pembahasan \\ Ekstraksi}

Hasil ekstraksi $100 \mathrm{~g}$ tanaman patah tulang dengan pelarut etanol adalah 10,163 g. Menggunakan metode maserasi karena metode ini sangat mudah dan tidak menggunakan panas. Hal ini sangat berpengaruh pada proses ekstraksi dimana tidak adanya penambahan panas yang menyebabkan ekstrak mengalami kerusakan senyawa aktif atau yang dikenal biasa disebut dengan proses denaturasi. Pelarut yang digunakan dalam proses ekstraksi adalah pelarut polar yaitu etanol, karena etanol merupakan pelarut yang sangat baik untuk ekstraksi pendahuluan karena dapat mengekstraksi senyawa polar dan non polar. Kandungan air yang terdapat pada etanol dapat mengekstraksi senyawa-senyawa yang kebanyakan bersifat polar sedangkan etanol mempunyai dua gugus yang berbeda kepolarannya, yaitu gugus hidroksil yang bersifat polar dan gugus alkil yaitu $\mathrm{CH}_{3}$ - $\mathrm{CH}_{2}$ - yang bersifat non polar. Adanya kedua gugus pada etanol diharapkan senyawa-senyawa dengan tingkat kepolaran yang berbeda akan terekstrak dalam etanol (Harborne, 1987).

\section{Aktivitas Antiinflamasi Ekstrak Etanol Tanaman Patah Tulang}

Pengujian efek antiinflamasi ini menggunakan tanaman patah tulang sebagai sampel karena adanya senyawa fitokimia yang terkandung didalamnya yang diduga bersifat sebagai antiinflamasi. Menurut Baud (2014) ekstrak etanol batang segar dan kering tanaman patah tulang positif terdapat senyawa flavonoid, steroid dan tannin. Dalam penelitian antiinflamasi ini metode yang digunakan adalah pembentukan udem buatan pada telapak kaki tikus dengan menggunakan karagenan sebagai penginduksi udem. Metode ini dipilih karena merupakan salah satu metode pengujian aktivitas antiinflamasi yang sederhana, mudah dilakukan dan sering dipakai (Fitriyani et al., 2011). Hasil pengukuran volume udem ekstrak etanol tanaman patah tulang dapat dilihat pada Gambar 1

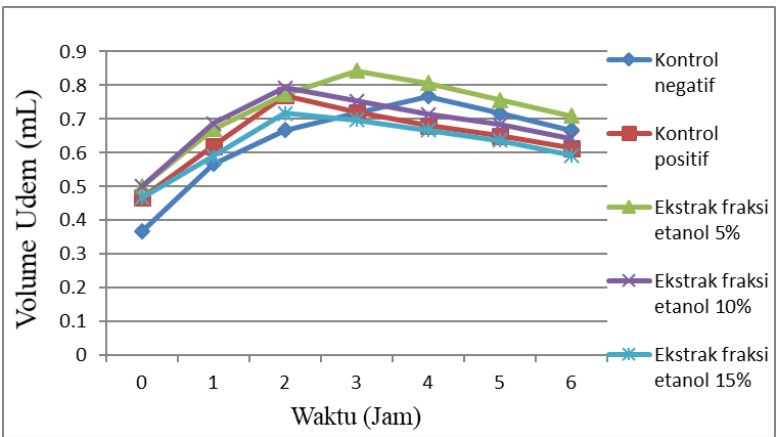

Gambar 1. Grafik hubungan rata-rata volume udem dengan waktu

Dari hasil pengukuran volume udem, kelompok kontrol negatif mengalami kenaikan volume udem hingga jam ke-4, sedangkan pada kelompok kontrol positif, dosis $10 \%$ dan dosis $15 \%$, peningkatan persentase udem hanya terjadi sampai jam ke-2 dan kemudian mulai mengalami penurunan di jam ke-3. Berbeda dengan dosis $5 \%$ yang terjadi peningkatan volume udem sampai jam ke-3 dan kemudian mulai mengalami penurunan di jam ke-4. Berdasarkan hasil perhitungan rata-rata persen udem, ekstrak etanol semua dosis kelompok zat uji menunjukkan adanya efek antiinflamasi dimana rata-rata persen udem setiap kelompok zat uji setara dengan persen udem kontrol positif dan tidak sebesar persen udem pada kelompok kontrol negatif. Persen udem pada kontrol negatif terus meningkat mulai dari jam ke 1 sampai jam ke 4 dan mengalami penurunan pada jam ke 5 sampai jam ke 6 sedangkan pada masingmasing kelompok uji persen udem lebih cepat mengalami penurunan seperti kontrol positif. Ilustrasi tersebut juga dapat terlihat pada diagram batang pada Gambar 2.

Hasil perhitungan persen inhibisi udem ekstrak etanol tanaman patah tulang pada kelompok perlakuan ekstrak 5\% kemampuan menghambat udem tidak sebagus kontrol positif yaitu pada jam ke 4 sebesar 41,41\%. Pada kelompok perlakuan ekstrak 10\% mampu menghambat udem setara dengan kontrol positif yaitu pada jam ke 3 sebesar 46,53\%. Dan pada kelompok perlakuan ekstrak 15\% mampu menghambat udem seperti kontrol positif pada jam ke 3 sebesar 45,23\%. Berdasarkan hasil penelitian ini terlihat bahwa pada fraksi etanol semua dosis kelompok zat uji menunjukkan adanya efek antiinflamasi namun dosis yang paling baik dalam penghambatan radang adalah dosis $10 \%$.

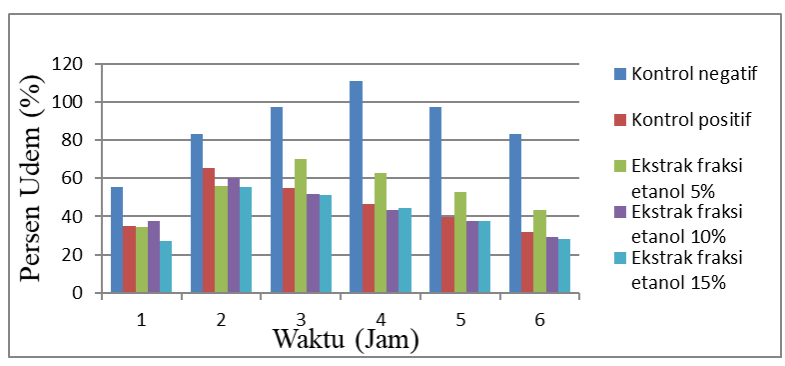

Gambar 2. Grafik Hubungan persen udem dengan wakt 
Seharusnya dengan meningkatnya dosis atau konsentrasi, maka aktivitas antiinflamasi akan menunjukkan adanya peningkatan. Tetapi ternyata pada dosis $15 \%$ justru terjadi penurunan aktivitas antiinflamasi. Hal tersebut disebabkan memang terdapat beberapa jenis obat dalam dosis yang lebih tinggi justru menyebabkan pelepasan histamin secara langsung dari mast cell sehingga mengakibatkan pembuluh darah menjadi lebih permeable terhadap cairan plasma dan menimbulkan proses peradangan (Fitriyani et al., 2011). Maka dimungkinkan pada ekstrak etanol tanaman patah tulang ini mengandung senyawa yang mampu mengakibatkan hal tersebut. Ilustrasi tersebut juga dapat terlihat pada Gambar 3.

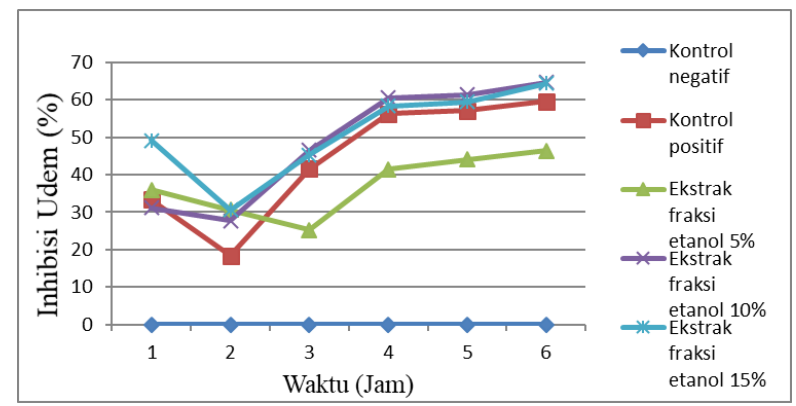

Gambar 3. Grafik Hubungan persen inhibisi udem dengan waktu

Dari penelitian ini diperoleh bahwa ekstrak etanol tanaman patah tulang pada dosis $10 \%$ dan dosis $15 \%$ memiliki potensi yang besar dalam menghambat inflamasi yang ditunjukkan dengan persen inhibisi secara keseluruhan hingga 50\% atau lebih. Dimana persyaratan sebagai obat antiradang (antiinflamasi) adalah mampu menurunkan volume radang sebesar 25\% atau lebih (Siswandono dan Soekardjo, 1995). Selain itu tanaman patah tulang juga memiliki aktivitas antiinflamasi karena mengandung senyawa metabolit sekunder. Tanaman patah tulang mengandung senyawa alkaloid, tanin, flavonoid, steroid, triterpenoid, dan hidroquinon (Toana dan Nasir, 2010). Efek antiinflamasi dapat dilihat dari kandungan yang terdapat pada ekstrak tanaman patah tulang yaitu senyawa golongan alkaloid, flavonoid, saponin, steroid dan tanin yang telah diketahui memiliki efek antiinflamasi (Morshed, 2011).

Selain itu Flavonoid juga memiliki efek antiinflamasi melalui mekanisme penghambatan aktivitas enzim siklooksigenase/lipooksigenase secara langsung sehingga menyebabkan penghambatan biosintesis eikosanoid dan leukotrin (Hidayati, 2008).

Dari hasil uji normalitas dan homogenitas diketahui bahwa data persen hambatan inflamasi berdistribusi normal dan homogen dengan $p>0,05$. Sehingga dilanjutkan dengan uji One Way ANOVA dengan post hoc test yaitu uji LSD. Dari hasil uji One Way ANOVA diketahui bahwa kelompok perlakuan setiap dosis tidak memiliki perbedaan bermakna dengan kelompok kontrol positif. Hal tersebut menunjukkan bahwa kelompok perlakuan setiap dosis memiliki aktivitas sebagai agent antiinflamasi sebab memiliki aktivitas yang tidak berbeda secara bermakna dengan kelompok kontrol positif.

\section{Kesimpulan}

Ekstrak etanol tanaman patah tulang pada dosis $5 \%, 10 \%$ dan dosis $15 \%$ memiliki aktivitas antiinflamasi dan dapat menurunkan udem dengan cepat setara dengan kontrol positif (Natrium diklofenak) dan berbeda dengan kontrol negatif. Dosis ekstrak etanol yang paling baik dalam menurunkan udem adalah dosis $10 \%$.

\section{Daftar Pustaka}

Agral, O., Fatimawali, Yamlean P., dan Supriati H. S. 2013. Formulasi dan Uji Kelayakan Sediaan Krim Anti Inflamasi Getah Tanaman Patah Tulang (Euphorbia tirucalli L.). Jurnal Ilmiah Farmasi. 2(2): 1-3.

Dalimartha, S., 2003. Atlas Tumbuhan Obat Indonesia Jilid 5. Pustaka Bunda, Jakarta.

Harborne, J. B., 1987. Metode Fitokimia, Penuntun Cara Modern Menganalisis Tumbuhan. ITB, Bandung.

Julianus, K., Diah I., Supratman T., Harwiyadin K., Yermias K., Syamsir S., dan Moody C. K., 2011. Tumbuhan Obat Tradisional Di Sulawesi Utara Jilid 1. ISBN: 978-602-98144-1-5, Manado.

Mangan, Y., 2009. Solusi Sehat Mencegah dan Mengatasi Kanker. Agromedia pustaka, Jakarta.

Morshed, G. 2011. Evaluation of Analgesic and AntiInflammatory Effect of Terminalia Arjuna Ethanol Extract. IJPSR. 2(10): 2577-2585.

Mycek, M. J., Harvey R.A., dan Champe P.C., 2001. Farmakologi Ulasan Bergambar, Ed. 2. Widya Medika, Jakarta.

Santoso, S., 2008. Panduan Lengkap Menguasai Statistik dengan SPSS 16. PT. Elex Media Komputindo, Jakarta.

Sari. 2006. Pemanfaatan Obat Tradisional dengan Pertimbangan Manfaat dan Keamanannya. Majalah IImu Kefarmasian. 1(3): 1-7.

Setyoadi dan Sartika D. D. 2010. Efek Lumatan Daun Dewa (Gynura segetum) dalam Memperpendek Waktu Penyembuhan Luka Bersih pada Tikus Putih. Jurnal Keperawatan Soedirman. 1(3): 127-135.

Siswandono dan Soekarjo. 1995. Ilmu Patologi. Kedokteran EGC, Jakarta.

Toana, M. H. dan Nasir B. 2010. Studi Bioaktif dan Isolasi Senyawa Bioaktif Tumbuhan Euphorbia tirucalli (Euphorbiaceae) sebagai Insektisida Botani Alternatif. Journal Agroland. 17(1): 47-55.

Yi, Q., Zarina W. Z., Nurulhidayah C., Ezany M. Y., Azlina A. Dan Suharni M. 2017. The Antibacterial Properties of Euphorbia tirucalli Stem Extracts Against Dental Caries Related Bacteria. Journal Med. \& Health. 12(1): 34-41. 